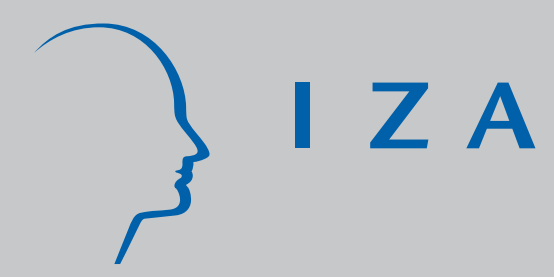

IZA DP No. 3736

Evaluation of an In-Work Tax Credit Reform in Sweden: Effects on Labor Supply and Welfare Participation of Single Mothers

Rolf Aaberge

Lennart Flood

September 2008 


\title{
Evaluation of an In-Work Tax Credit Reform in Sweden: Effects on Labor Supply and Welfare Participation of Single Mothers
}

\author{
Rolf Aaberge \\ Statistics Norway and IZA \\ Lennart Flood \\ University of Gothenburg and IZA
}

Discussion Paper No. 3736

September 2008

\author{
IZA \\ P.O. Box 7240 \\ 53072 Bonn \\ Germany \\ Phone: +49-228-3894-0 \\ Fax: +49-228-3894-180 \\ E-mail: iza@iza.org
}

\begin{abstract}
Any opinions expressed here are those of the author(s) and not those of IZA. Research published in this series may include views on policy, but the institute itself takes no institutional policy positions.

The Institute for the Study of Labor (IZA) in Bonn is a local and virtual international research center and a place of communication between science, politics and business. IZA is an independent nonprofit organization supported by Deutsche Post World Net. The center is associated with the University of Bonn and offers a stimulating research environment through its international network, workshops and conferences, data service, project support, research visits and doctoral program. IZA engages in (i) original and internationally competitive research in all fields of labor economics, (ii) development of policy concepts, and (iii) dissemination of research results and concepts to the interested public.
\end{abstract}

IZA Discussion Papers often represent preliminary work and are circulated to encourage discussion. Citation of such a paper should account for its provisional character. A revised version may be available directly from the author. 
IZA Discussion Paper No. 3736

September 2008

\section{ABSTRACT \\ Evaluation of an In-Work Tax Credit Reform in Sweden: Effects on Labor Supply and Welfare Participation of Single Mothers ${ }^{*}$}

The purpose of this paper is to evaluate a recent Swedish in-work tax credit reform where we pay particular attention to labor market exclusion; i.e. individuals in as well as outside the labor force are included in the analysis. To highlight the importance of the joint effects from the tax and the benefit systems it appears particular relevant to analyze the labor supply behavior of single mothers. To this end, we estimate a structural microeconometric model of labor supply and welfare participation. The model accounts for heterogeneity in consumptionleisure preferences as well as for constraints in job opportunities. The results of the evaluation show that the reform generates welfare-gains for virtually every single mother, and moreover benefits low-income households. Finally, due to increased labor supply and decline in welfare participation we find that this reform is almost self-financing.

JEL Classification: J22, I38

Keywords: labor supply, single mothers, in-work tax credit, social assistance, random utility model

Corresponding author:

Lennart Flood

Department of Economics

School of Business, Economics and Law

University of Gothenburg

Box 640

S-405 30 Göteborg

Sweden

E-mail: Lennart.Flood@handels.gu.se

\footnotetext{
* We would like to thank Tom Wennemo for skilful programming assistance. Financial support from the Norwegian Council of Research and the Jan Wallander and Tom Hedelius Foundation for Research in Economics are gratefully acknowledged.
} 


\section{Introduction}

During the recent decade a debate in the OECD countries on reforming the tax-transfer treatment of disadvantaged households has turned on two issues. The first one concerns the possibly large loss in efficiency due to disincentives and distortions on worker behaviour caused by high marginal tax rates for small and medium income levels. The second issue stems from the widespread observation that the system of transfers and benefits directly or indirectly related to supporting the life standard of disadvantaged households performs rather poorly in terms of cost-effectiveness. This concern motivated the Swedish Government to introduce an in-work tax credit reform in 2007, which was further extended in 2008. As a result of the reform the government expected a major reduction in the number of individuals depending on the welfare system ${ }^{1}$. The purpose of this paper is to analyse the efficiency as well as the welfare effects from the 2008 version of the in-work tax credit reform for single mothers with particular focus on the "outsiders" of this group. Single mothers stand out as the household type with the largest proportion of "outsiders" that strongly depend on support from the welfare system. Accordingly, it is of major importance to include "outsiders" in the population under study. However, since it might not make sense to assume that the "outsiders" face equally attractive job opportunities as the "insiders" it is strictly important to use a model of labour supply that account for heterogeneity in job opportunities. As will be demonstrated in Section 3 the random utility model (RUM) of household labour supply used in this study is particularly appropriate for dealing with heterogeneity in job opportunities ${ }^{2}$. Our approach differs in important aspects from Blundell et al. (1987), who included unemployed people by using a generalized Tobit model. By contrast, the RUM framework allows for an integrated treatment of "insiders" and "outsiders" where it is accounted for heterogeneity in preferences for consumption-leisure as well as for possible differences in job opportunities.

At this stage it is natural to ask the question whether the inclusion of the "outsiders" address an important economic problem. The Swedish case offers an illustration; Figure 1.1 shows that the number of whole year equivalent working age individuals that are supported by the benefit system has doubled since 1970 and at present accounts for more than one million people, or approximately $20 \%$ of the working age population in Sweden. The largest group is those that receive disability pension, followed by long-term sick and unemployed persons. The conventional claim that these individuals will never be able to become employed is not supported by data. The increase of individuals outside the labor market cannot be explained by only exogenous changes, for instance health or medical reasons. Changes in compensation rates as well as in norms may partly explain the rise in the number

\footnotetext{
${ }^{1}$ In Swedish the group consisting of unemployed, long-term sick and disabled have been addressed as "utanförskapet" which is most closely translated as the outsiders. For convenience this term will be used in this paper.

${ }^{2}$ For previous applications, see Aaberge et al. (1995, 1999, and 2008).
} 
of people supported by the benefit system, see e.g. Johansson and Palme (2002) and Lindbeck et.al. (2007). Due to the reduction in lower unemployment benefit and stricter monitoring, labor market exclusion has been reduced during the recent years. This paper will pursue the question of whether the implementation of the 2007/2008 in-work tax credit reform has contributed to a further reduction in welfare participation.

(Figure 1.1 about here)

The major motivation for introducing policies that reduce the number of individuals dependent on support from welfare is to reduce poverty as well as the central government budget expenditures. To reduce poverty during the active working age means reducing the risk of enduring health/mental problems as well as life-long poverty, see e.g. Beland, et. al. (2002). The central governmental budget effect on going from welfare to work is substantial. As an illustration, an individual that is moving from full time on disability pension to full time working yields a yearly net contribution of almost SEK $300000^{3}$. Thus, about 400000 "whole-year equivalents" has a potential budget effect of SEK 120 billion or about $15 \%$ of total central governments expenditures (SEK 781 billion) in 2008 .

Several studies have evaluated the expected labor supply effects from introducing in-work tax credits in the US and the UK. The most recent and relevant studies for our purpose are for the U.K. Blundell and Hoynes (2004) and Duncan and Giles (1998) and for the U.S. Meyer and Rosenbaum (2001) and Fang and Keane (2004). The results from these studies suggest that there are strong incentive effects from tax credits. The broadening of the tax credit seems to have contributed to increased labor force participation and reduced welfare participation.

Only a few studies have focused attention on the joint effects from taxes and benefits on single mother's labor supply behavior and welfare participation. In a recent paper Flood et al. (2007) have analyzed the effect of an in-work tax credit on the labor supply and welfare participation of single mothers in Sweden. However, in contrast to this study, "outsiders" was excluded from the population under study. By contrast Lundgren et. al. (2008) provides an evaluation of the Swedish 2007/08 inwork tax credit reform based on a binary logit models for unemployment, disability and long term sickness, whereas this paper offers an evaluation based on a structural modeling framework.

The data used for this study is the 2004 wave from the Swedish Longitudinal Individual Data (LINDA). LINDA is completely based on register-information, and thus provides high-quality tax and income data. There is no problem with under-reporting of welfare participation which is a major problem in traditional survey-data. Moreover, LINDA combined with a detailed tax benefit program, provides very precise budget-sets for different hours of work combinations.

\footnotetext{
${ }^{3}$ Own calculations, based on a large sample of individuals in the database LINDA who receive disability pension. We calculate the revenues from taxes (income and payroll), VAT, childcare fees and the expenditures on social assistance,
} 
The paper is organized as follows. Section 2 presents the main features of the Swedish income tax and benefit systems and the tax and benefit reform implemented in 2007. The microeconomic labor supply model and the corresponding empirical specification are presented in Section 3. Section 3 also reports estimation results and wage and income elasticities of labor supply, whilst the data are described in Appendix 1. The social evaluation framework used in this study is presented in Section 4. Section 5 reports the results of the tax reform evaluation and Section 6 summarizes our findings.

\section{Income taxes and means-tested welfare programs in Sweden}

\subsection{Taxes and benefits}

The Swedish income tax system consists of two parts, a flat municipal tax and a progressive national tax regime for earnings as well as for non-labour income. The individual is the taxation-unit and income taxes are independent of marital status. The flat municipal tax rate varies across municipalities; the average municipal tax-rate in 2007 was 31.55 percent, the lowest 28.89 and the highest 34.24. The national tax is based on three income-brackets. Incomes lower than SEK 340,900 $\left(\$ 37,054^{4}\right)$ are tax-free, while incomes up to SEK $507,100(\$ 55,120)$ were taxed by a 20 percent rate and incomes above SEK 507,100 were taxed by a 25 percent rate.

Figure 2.1 displays the marginal and average tax rates for the income year 2008. In order to highlight the importance of the in-work tax credit reform, Figure 2.1 also show taxes before the reform. The marginal taxes before the reform have an irregular shape up to SEK 340,900 (\$37,054), the break point for governmental tax. This shape is explained by the phase-in and phase-out of a basic tax deduction. This basic tax deduction remains unchanged after the reform but the tax credit is designed such that it smooth's the irregularities created by the basic deduction. The result is an increasing step-wise marginal tax rate with the following tax rates and kink points (for an average municipal tax rate). Zero tax rate up to a taxable income of SEK 38,000 , next $25 \%$ up to SEK $112,000,31 \%$ up to SEK 288,000, $32 \%$ up to SEK 340,900, $52 \%$ up to SEK 507,100 and finally 57 $\%$.

(Figure 2.1 about here)

housing allowance and disability pensions assuming full time market work and then for full time disability pension. On average the governmental budget effect of going from disability to work is SEK 287,659. 
The distribution of gross (taxable) income show that most single mothers face a marginal tax rate close to the municipal tax rate, only a few reach the breakpoint for governmental tax rate and very few pay the highest rate. Evaluation of the impact of the tax reform shows that most single mothers face lower marginal tax rates. The only exception are those that have higher incomes than the breakpoint. Accordingly, the average tax rate declines for everyone with a positive labor income, but much more for low than for high incomes. However, since the tax credit only applies for income from work, the tax reform increase the incentives for transitions to job participation for those who did not work before the reform. The incentive effects for those who were working before the reform are mixed. Below the breakpoint the marginal tax rates have been reduced except for the second bracket. For high income earners located above the breakpoint, marginal taxe rates are unchanged but the average taxes have declined. Thus, a negative income effect might result in reduced working hours for high income earners. Finally, note that the reform results in a substantial tax cut, especially for low income earners. For an income of SEK 150,000 the average tax rate is $20 \%$ and at 250,000 about 25 $\%$.

Although the purpose of this paper is to evaluate the 2007/2008 tax reform the result of the evaluation might be biased if we don't account for the impact of three means-tested programs; social assistance, housing allowance, and cost of childcare.

Social assistance is supposed to be the ultimate safety net for people having temporary economic problems. Individuals are not entitled to social assistance if they have money in a bank account or other assets, which mean for example that unemployment benefits, national child allowance, sickness benefits, and various pensions, must be exhausted first. Social assistance is determined by nationwide rules supposed to provide "decent" living, and thus depends on household composition. To be entitled to social assistance, a household must have an income below the maximum benefit-level. There is then an implicit tax-rate of 100 percent on social assistance as household income increases.

Housing allowance is also determined by nationwide rules. The amount of housing allowance a household is entitled is determined by household total income, rent, the number of children and the age of the parents.

The maximum-childcare fee-reform, which was implemented in 2002, is based on household income, but only up to a rather low ceiling above which the fee is constant. For the first child the fee is 3 percent, for the second child 2 percent, and for the third child 1 percent of gross household income. No fees are charged for further children. The ceiling is set fairly low, and as a result most households paid the monthly maximum amount SEK 1,260(\$137), 840(\$91), and 420(\$46) for the first, second, and third child in child care.

Figure 2.2 illustrates how social assistance, housing allowance, and cost of childcare vary with

\footnotetext{
${ }^{4}$ Using a purchasing power adjusted exchange rate in 2007 of $\$ 1=$ SEK 9.20
} 
disposable income for a low-income single mother with two children, ages 2 and 4 . The two lines at the upper part of the graph show disposable income before and after the reform. This specific lowincome household will not receive increased income after tax by increasing labour supply from zero hours of work to more than 1,000 hours/year primarily because of reduced social assistance and housing allowance whereas cost for child care (shown as a negative number) plays a minor role. The two lines at the bottom of Figure 2.2 show taxes before and after the tax-credit reform. Since this household never reaches the break-point in the tax system, not even at 2,000 hours of work, taxes increase almost linearly. The tax cut produces a similar increase in disposable income once the income exceeds the ceiling for social assistance. The above discussion demonstrates that it is crucial for the tax reform evaluation to account for the fact that the tax cut is largely neutralized by the benefit systems for low income households. Otherwise there is a risk that the behavioral effect of the taxcredit reform will be exaggerated.

(Figure 2.2 about here)

\subsection{The in-work tax credit reform}

The implication of the reform, expressed in marginal and average taxes were discussed above, here we take a closer look at the profile of the in-work tax credit and the related basic deduction scheme.

To avoid choosing low hours of work most in-work tax credits programs has a phase in region and to avoid an income support to wealthy households there is also typically a phase out region. However, the Swedish design, implemented in 2007 and further extended in 2008, differs from the mainstream design; it has no phase out region and the credit applies for all individuals with income from work, thus there is no low income target group. Moreover, unlike the US and UK reform the credit is not refundable.

Figure 2.3 shows the profiles of the in-work tax credit system and the basic tax deduction scheme. The basic deduction, which all individuals can claim, reduces taxable income (the income base for municipal and governmental tax). The basic deduction have three levels depending on the level of taxable income; SEK 17,500, 31,800 and 12,100. The in-work tax credit, which is deducted from the tax rate, increase with taxable income and have three levels; SEK 0, 6,500 and 14,500.

(Figure 2.3 about here)

The tax credit reform applies for all individuals with an income from work. In the governmental budget proposal for 2008 the cost of this reform is estimated to about SEK 50 billion, when one presupposes that there are no behavioral effects from the reform. In a recent evaluation, allowing for changes in working hours, Lundgren et. al. (2008), report a slightly smaller deficit. 
Finally it should also be mentioned that the tax reform evaluated in this study also includes a change in unemployment benefit, implemented in 2007. This change is a reduction in the replacement; the highest rate is lowered from SEK 730 to 680 per day and from day 1-200 the replacement rate is $80 \%$, from $201-30070 \%$ and after that $65 \%$. However, the effects reported in this study are completely dominated by the in-work tax credit.

\section{The Behavioral modeling framework}

\subsection{The structural labor supply model}

The model used in this paper can be considered as an extension of the standard multinomial logit model and differs from the traditional models of labor supply by characterizing behavior in terms of a comparison between utility levels rather than between marginal variations of utility ${ }^{5}$. We assume that a single mother chooses a "job" from a choice set $B$ that may differ across individuals. Each job alternative in B contains a wage rate $w$, hours of work $h$ and other observed and unobserved (for the analyst) job characteristics $\mathrm{s}$ and $k$ such as environmental characteristics and skill content of the job, and whether or not the single mother is eligible for social assistance benefit. Moreover, $B$ contains also non-market activities (i.e. alternative allocations of "leisure"), i.e. jobs with $w=0$ and $h=0$ that can or cannot be combined with receipt of social assistance benefit. The utility functions for single mothers are assumed to be of the following form

$$
U(f(w h, I, b(z)), h, z, s, k)=v(f(w h, I, b(z)), h, z, s) \varepsilon(w, h, z, s, k)
$$

where $v$ and $\varepsilon$ represent the systematic and the random component, respectively, $z=1$ if the single mother receives social assistance ( 0 otherwise), $b(z)$ is the social assistance benefit level $(b(0)=0), f$ is a function determined by the tax and benefit rules that transforms gross income into income after tax, i.e. $f(w h, I, b(z))$ is disposable income (income after tax and benefits), $I$ is exogenous income and $\mathrm{k}$ is a variable that is supposed to capture the impact of unobserved job characteristics. The reason for treating $\mathrm{z}$ as an endogenous variable is due to the fact that there can be negative effects associated with receiving social assistance, which might explain why some people that are eligible for social assistance benefit don't receive it ${ }^{6}$. The random term $\varepsilon$ accounts for the effect on the utility of all the

\footnotetext{
5 This approach has been used by Aaberge, Dagsvik and Strøm (1995), Aaberge, Colombino and Strøm, (1999 and 2004) and Aaberge, Colombino and Wennemo (2006). A simplified discrete version of this approach has been used by e.g. Dickens and Lundberg (1993), Euwals and van Soest (1999), Flood, Hansen and Wahlberg (2004) and Labeaga, Oliver and Spadaro (2007).

${ }^{6}$ In Moffit (1983) this is referred to as a stigma effect.
} 
characteristics of the job match which are observed by the individual but not by the analyst and thus accounts for variation in tastes for a given job across individuals as well as across job opportunities for a given individual. Thus, the single mothers are assumed to make their labor supply choices according to $(3.1)$.

By assuming that $\varepsilon$ is type I extreme value distributed and that the specification (3.1) is valid, it turns out that the probability density that opportunities with hours $h$ and wage rate $w$ in sector $s$, where the single mother receives $(z=1)$ or does not receive $(z=0)$ social assistance benefit. ${ }^{7}$

$$
\varphi(h, w, s, z) \equiv \operatorname{Pr}\left[U(f(w h, I, b(z)), h, s, z)=\max _{(x, y, i, j) \in B} U(f(x y, I, b(j)), y, i, j)\right]=
$$

$v(f(w h, I, b(z)), h, s, z) p_{1 z} g(h, w, s, z)$

$v(f(0, I, 0), 0, \cdot, 0) p_{00}+v(f(0, I, b(1)), 0, \cdot, 1) p_{01}+\sum_{i=0,1} \sum_{j=0,1} \int_{x>0} \int_{y>0} v(f(x y, I, b(j)), y, i, j) p_{1 j} g(x, y, i, j) d x d y$

for $\{h, w\}>0$ and

$$
\varphi(0,0, \cdot, z)=
$$

$m(z)$

$$
v(f(0, I, 0), 0, \cdot, 0) p_{00}+v(f(0, I, b(1)), 0, \cdot 1) p_{01}+\sum_{i=0,1} \sum_{j=0,1} \int_{x>0} \int_{y>0} v(f(x y, I, b(j)), y, i, j) p_{1 j} g(x, y, i, j) d x d y
$$

for $\{h, w\}=0$, where

$$
m(z)= \begin{cases}v(f(0, I, 0), 0, \cdot, 0) p_{00} & \text { if } z=0 \\ v(f(0, I, b(1)), 0, \cdot, 1) p_{01} & \text { if } z=1,\end{cases}
$$

$p_{00}, p_{01}, p_{10}$ and $p_{11}$ are the proportions of opportunities in $\mathrm{B}$ that are non-market opportunities where the single mother is not eligible for social assistance benefit, non-market opportunities where the single mother is eligible for social assistance benefit, market opportunities where the single mother is

\footnotetext{
${ }^{7}$ For the derivation of the choice density (3.2), see Aaberge, Colombino and Strøm (1999). Note that (3.2) can be considered as a special case of the more general multinomial type of framework introduced by Dagsvik (1994).
} 
not eligible for social assistance benefit and market opportunities where the single mother is eligible for social assistance benefit. Thus, $p_{00}+p_{01}+p_{10}+p_{11}=1$. Furthermore, $g(h, w, s, z)$ is the density of choice opportunities which can be interpreted as the relative frequency (in the choice set) of opportunities with hours $h$ and wage rate $w$ in sector s, where the single mother is $(z=1)$ or is not $(z=0)$ eligible for social assistance benefit.

Opportunities with $h=0$ (and $w=0)$ are non-market opportunities (i.e. alternative allocations of "leisure"). Note that the sector variable $s$ vanishes and is replaced by the symbol · in this case. Thus, the density defined by (3.2) - (3.4) will form the basis of estimating the parameters of the utility function and the choice sets.

\subsection{Empirical specification}

Since we observe the chosen job (s, h and w) and whether the single mother is social assistance recipient or not, the density (3.2) - (3.4) will form the basis of estimating the parameters of the utility function and the choice sets. To this end we use the following specification of the systematic part of the utility function (3.1)

$$
\begin{aligned}
& \ln v(f(w h, I, b(z)), h, z, s)=\alpha_{2}\left(\frac{f(w h, I, b(z))^{\alpha_{1}}-1}{\alpha_{1}}\right)+\left(\alpha_{4}+\alpha_{5} \log A+\alpha_{6}(\log A)^{2}+\alpha_{7} C h_{1}+\right. \\
& \left.\alpha_{8} C h_{2}+\alpha_{9} C h_{3}+\alpha_{10} s+\alpha_{11} t\right)\left(\frac{L^{\alpha_{3}}-1}{\alpha_{3}}\right)+\alpha_{12} z\left(\frac{L^{\alpha_{3}}-1}{\alpha_{3}}\right)-\sum_{j=1}^{7} \tau_{j} Q_{j} z
\end{aligned}
$$

where $L$ is leisure, defined as $L=1-(h / 8736), s=1$ if the job belongs to the private sector $(=0$ otherwise), $z=1$ if the level of social assistance is equal or above SEK 12,000 and 0 otherwise, A is age and $\mathrm{Ch}_{1}, \mathrm{Ch}_{2}$ and $\mathrm{Ch}_{3}$ are number of children below 1-5, 6-12 and 13-17 years old, $\mathrm{t}=1$ if the individual is involuntary unemployed, disabled or suffer from long-term sickness, and the Q-variables are defined in Table 2.1. Note that the latter term of (3.5) captures the possible disutility from being a social assistance recipient.

In the specification of the probability density of opportunities $p_{00} g(h, w, s, z)$ we will assume that offered hours and offered wages are independently distributed. The justification for this is that offered hours, in particular normal working hours, are typically set in rather infrequent negotiations between employers and employees associations, while wage negotiations are far more frequent in which the hourly wage tend to be set independent of working hours. For the sake of estimation it is convenient to divide both numerator and denominator by $p_{00}$ and define $g_{01}=p_{01} / p_{00}$ and 
$g_{1 z}=p_{1 z} / p_{00}$. Thus, we specify the density of opportunities in sector $s$ requiring $h$ hours of work and paying hourly wage $w$ as follows

$$
g_{1 z} g(h, w, s, z)=g_{1 s}(w) g_{2 s}(h) g_{3}(s, z)
$$

where $g_{1 s}(w), g_{2 s}(h)$ and $g_{3}(s, z)$ are respectively the densities of wages, hours, and opportunities in sector s with and without eligibility for social assistance benefit, given that the opportunity is a market job.

We can then rewrite the choice density (3.2)-(3.3) as follows

$\varphi(h, w, z, s)=$

$v(f(w h, I, b(z)), h, z, s) g_{1 s}(w) g_{2 s}(h) g_{3}(s, z)$

$v(f(0, I, 0), 0, \cdot, 0)+v(f(0, I, b(1)), 0, \cdot, 1) g_{01}+\sum_{i=0,1} \sum_{j=0,1} \int_{x>0} \int_{y>0} v(f(x y, I, b(j)), y, j, s) g_{1 i}(x) g_{2 i}(y) g_{3}(i, j) d x d y$

for $\{h, w\}>0$ and

$\varphi(0,0, z, \cdot)=$

$\tilde{m}(z)$

$v(f(0, I, 0), 0, \cdot, 0)+v(f(0, I, b(1)), 0, \cdot, 1) g_{01}+\sum_{i=0,1} \sum_{j=0,1} \int_{x>0} \int_{y>0} v(f(x y, I, b(j)), y, j, s) g_{1 i}(x) g_{2 i}(y) g_{3}(i, j) d x d y$

for $\{h, w\}=0$, where

$$
\tilde{m}(z)=\left\{\begin{array}{l}
v(f(0, I, 0), 0, \cdot, 0) \quad \text { if } z=0 \\
v(f(0, I, b(1)), 0, \cdot, 1) g_{01} \quad \text { if } z=1
\end{array}\right.
$$


Let us now turn to the specification of the opportunity sets given by the distributions $g_{1 s}(w), g_{2 s}(h)$ and $g_{3}(s, z)$. The sector-specific densities of offered wages are assumed to be lognormal with mean that depends on length of schooling $(E d)$ and on past potential working experience (Exp), where experience is defined to be equal to age minus length of schooling minus five, i.e.

$$
\log w=\beta_{s 0}+\beta_{s 1} \frac{E x p}{100}+\beta_{s 2}\left(\frac{E x p}{100}\right)^{2}+\beta_{s 3} E d_{1}+\beta_{s 4} E d_{2}+\sigma_{s} \eta
$$

where $\eta$ is standard normally distributed.

The sector-specific distributions of offered hours are composed by three segments which include a possible peak corresponding to full time ( $f t, 35.5$ - 40.5 weekly hours) and different occurrence of jobs with hours that are respectively lower and higher than full-time. Thus, $g_{2 s}$ is given by

$$
g_{2 s}(h)=\left\{\begin{array}{lll}
\exp \gamma_{s 1} & \text { if } & h \in[1,35] \\
\exp \gamma_{s 2} & \text { if } & h \in[35.5,40.5] \\
\exp \gamma_{s 3} & \text { if } & h \in[41, H]
\end{array}\right.
$$

where $H$ is the maximum observed value of $h$. Since the density values must add up to $1, \gamma_{s 3}$ for $\mathrm{s}=0,1$ is given by

$$
(35-1) \exp \gamma_{s 1}+(40.5-35.5) \exp \gamma_{s 2}+(H-41) \exp \gamma_{s 3}=1
$$

Moreover, let $\quad \theta=\log g_{01}$ and

$$
g_{3}(s, z)=\exp \left(\left(\mu_{11}+\mu_{12} t\right) s z+\left(\mu_{21}+\mu_{22} t\right) s(1-z)+\left(\mu_{31}+\mu_{32} t\right)(1-s) z+\left(\mu_{41}+\mu_{42} t\right)(1-s)(1-z)\right)
$$


where $\mathrm{z}=1$ if the available job opportunity (in sector s) can be combined with being a social assistance recipient. In Table 4.1 we refer to $\gamma$ and $\mu$ as the parameters of the job opportunity density.

\subsection{Estimation results and labor supply elasticities}

\subsubsection{Estimation results}

The estimated parameters of the labour supply model are presented in Table 3.1 and 3.2. Since the model are rather complex and several parameters capture non-linear or interaction effects most parameters don't offer a simple straightforward interpretation.

The estimates displayed in Table 3.1 imply that the deterministic part of the utility function is an increasing and strictly concave function of leisure and consumption. The crucial parameters of the utility function are the shape parameters $\alpha_{1}$ and $\alpha_{3}$. These parameters are measured with high precision. Moreover, the marginal utility of leisure also depends on personal characteristics such as age and number of children for different ages, on whether the job is in the private or public sector and on an indicator for "outsider". As expected young children have a positive effect on the value of leisure, however there is no significant effect from the presence of older children. The parameter $\alpha_{10}$ associated with choice of sector is not significantly different from 0 which suggests that that is equally easy to combine being a single mother and work in the private as in the public sector. The effect of being classified as an "outsider" $\left(\alpha_{11}\right)$ shows a strong positive effect on the value of leisure, which of course reflects low working hours in this group. However, note that the modeling framework used in this study also account for the fact that "outsiders" face poorer job opportunities than "insiders".

(Table 3.1 about here)

The estimated parameters $\left(\tau_{1}-\tau_{7}\right)$ of the disutility from being a social assistance recipient show that foreign born single mothers have a smaller disutility (smaller stigma) than an ethnic Swedish single mother. Moreover, single mothers with young children and low education get less disutility than single mothers with older children and higher education. Given that the mother is entitled to social assistance (an income below the norm), the model predicts that the take up ratio is higher for individuals with a small stigma effect.

Table 3.2 presents the parameters for the job opportunity densities. The estimated $\theta$ parameter shows as expected that more non-market opportunities than market opportunities allow to be combined with the receipt of social assistance benefit. By comparing the $\mu$ parameters of Table 3.2 we 
find that "outsiders" face fewer job opportunities than insiders. However, since $\mu_{41}$ is not significantly different from 0 we cannot claim that the number of private sector opportunities which allow combination with the receipt of social assistance benefit differ between "insiders" and "outsiders". The estimated distributions of offered hours of work show a clear peak for full-time jobs in the public sector whereas there are fewer jobs with overtime hours than with part-time hours. By contrast, the private sector offers fewer part-time than jobs with overtime. Finally, as is demonstrated by Table 3.2 all coefficients of the wage densities are precisely estimated with signs as expected. Wages are strictly concave functions of experience and increasing with education.

(Table 3.2 about here)

\subsubsection{Wage and income elasticities}

To provide further information of the empirical model this sub-section presents labour supply elasticities. The wage elasticities are computed by means of stochastic simulations of the model since we (as analysts) do not observe all variables affecting preferences and opportunity sets. Draws are made from the distributions related to preferences and opportunities. Given the responses of each individual we then aggregate over the individuals to get various types of aggregate elasticities. Table 3.3 displays these elasticities. Since many individuals in this labor supply model of discrete choice will not react to small exogenous changes, the elasticities in Table 3.3 has been computed as an average of the percentage changes in labor supply from a 10 percent increase in the wage rates.

(Table 3.3 about here)

The second column of Table 3.3 gives the unconditional elasticities of labor supply, which means that the effects on participation as well as hours supplied are accounted for. The third column displays the elasticity of the probability of participation and the last column displays the elasticity of hours of work conditional on working. First row summarizes the average results for all individuals. The unconditional elasticity is 0.34 , the most important effect is on the probability of working, 0.3 , whilst the effect on hours given work is 0.1. Moreover, as found in similar studies on Italian (Aaberge et al., 1999) and Norwegian (Aaberge et al., 1995, 2008) data the elaticities show to decline sharply with income. For the poorest decile the wage elasticities are numerically quite high.

The estimated income elasticities are reported in Tables 3.4. Non-labor income comprises several income categories, which are unevenly distributed among households and do not change uniformly in our simulation experiments. Since the income elasticities are household specific, the aggregate labor supply response to a shift that involves changes in non-labor income is the result of a complex calculation. Table 3.4 shows how the elasticity of labor supply with respect to changes in these incomes depend on the location in the income distribution. Except for high income households, 
the income effect is rather small which is consistent with results obtained for Italian and Norwegian data.

\subsubsection{Prediction performance}

A comparison of the observed and simulated distribution of working hours is given in Figure 3.1.

Based on the estimated model simulated hours closely mimic the observed. The peak at zero hours as well as full time is closely replicated. Figure 3.2 gives the corresponding information only for the "outsiders" and again we find that the model reproduces the observed distribution of hours of work quite well.

(Insert Figures 3.1 and 3.2 here)

\section{The social evaluation framework}

Since the microeconomic model that is used in this study allows variation in preferences for consumption and leisure as well as in other observable and unobservable market and non-market opportunities it does not make sense to treat the estimated utility functions as comparable individual welfare functions. This is simply due to the fact that the social planner normally is unable to provide a convincing justification for discriminating between different preferences ${ }^{8}$. Thus, it is required to introduce measures of individual welfare that justify interpersonal comparisons. Section 4.1 explains the method used for dealing with this problem, whereas Section 4.2 discusses the methods that will be used for aggregating individual welfare levels.

\subsection{Specification and estimation of individual welfare functions}

As is universally recognized a social planner needs to compare gains in welfare of some to losses in welfare of others as part of the evaluation of a tax reform. It is non-controversial to assume that each individual's welfare increases with increasing income and leisure as is also captured by the householdspecific utility functions. However, since the preferences as specified in the behavioral model are heterogeneous, we face the problem of interpersonal comparability when the individual utilities are assumed to represent individual welfare levels. To solve the comparability problem the social planner may introduce an individual welfare function (a common utility function) ${ }^{9}$ which can be considered as

\footnotetext{
${ }^{8}$ See Boadway et al. (2002) and Fleurbaey and Maniquet (2006) for a discussion of interpersonal comparability of utility when preferences for leisure differ between individuals.

${ }^{9}$ Hammond (1991) argues for using a common utility function (individual welfare function) for all possible types of individuals. The common utility function determined by the social decision-maker justifies interpersonal comparability of both welfare levels and welfare differences.
} 
an integral part of the framework that the social planner uses as a basis for evaluating policy reforms. The formal definition of the individual welfare function $(V)$ determined by the social planner is given by eq. (3.5) where all variables, except income (after tax) and leisure, are replaced by the mean values of the sample. However, since the conclusions of the analysis may depend on the choice of the common utility function, a sensitivity analysis will be provided. To this end, we employ two additional alternative common utility functions derived from (3.5), where all variables, except income and leisure, are replaced by respectively the mean values of the poorest 10 percent and the richest 10 per cent of the sample of single mothers. To avoid any confusion note that the common utility functions are solely used as a basis for the social evaluation; it is not used for simulating labour supply and welfare participation choices. Thus, the simulated choices are the result of the maximization of the individuals' own utility function.

\subsection{Social Welfare Functions}

The informational structure of the individual welfare functions derived from (3.5) allows comparison of welfare gains and losses of different individuals due to a policy change. When evaluating the distribution of individual welfare effects of a tax system and/or a tax reform it is required to summarize the gains and losses by a social welfare function. The simplest welfare function is the one that adds up the comparable welfare gains ( $V$ defined by (3.5)) over individuals. However, since the linear additive social welfare function provides equal welfare weights to the single mothers, independent of whether they are poor or rich, this specific welfare function ignores a possible trade-off between efficiency and distributive considerations. Concern for distributive justice requires that poor individuals are assigned larger welfare weights than rich individuals, which is captured by the following family of rank-dependent welfare functions ${ }^{10}$,

$$
W_{k}=\frac{1}{n} \sum_{i=1}^{n} p_{k}\left(\frac{1}{n}\right) V_{i}, \quad k=1,2, \ldots
$$

where $V_{1} \leq V_{2} \leq \ldots \leq V_{n}$ is the ordered individual welfare levels $V$, and $p_{k}(t)$ is a weight function defined by

$$
p_{k}(t)= \begin{cases}-\log t, & k=1 \\ \frac{k}{k-1}\left(1-t^{k-1}\right), & k=2,3, \ldots\end{cases}
$$

\footnotetext{
${ }^{10}$ This family has its origin form Mehran (1976) and Yaari (1988). Several other authors have discussed rationales for rankdependent measures of inequality and social welfare, see e.g. Sen (1974), Hey and Lambert (1980), Donaldson and Weymark (1980, 1983), Weymark (1981), Ben Porath and Gilboa (1994) and Aaberge (2001).
} 
Note that the ethical justification behind the family of social welfare functions defined by (4.3) is equally convincing as the justification behind the traditional expected utility type of welfare functions. The essential differences between these two approaches for measuring social welfare arise from the so-called independence axioms. Whilst the expected utility independence axiom requires that the ordering of distributions of individual welfare is invariant with respect to identical mixing of the distributions being compared, the rank-dependent independence axiom requires that the ordering is invariant with respect to identical mixing of the inverses of the distributions being compared.

Note that the inequality aversion exhibited by $W_{k}$ decreases with increasing $\mathrm{k}$. As $k \rightarrow \infty, W_{k}$ approaches inequality neutrality and coincides with the linear additive welfare function defined by

$$
W_{\infty}=\frac{1}{n} \sum_{i=1}^{n} V_{i}
$$

It follows by straightforward calculations that $W_{k} \leq W_{\infty}$ for all $k$, and that $W_{k}$ is equal to the mean $W_{\infty}$ for finite $k$ if and only if the distribution of $V$ is the egalitarian distribution. Thus, $W_{k}$ can be interpreted as the equally distributed individual welfare level. As recognized by Yaari (1988) this property suggests that $I_{k}$, defined by

$$
I_{k}=1-\frac{W_{k}}{W_{\infty}}, k=1,2, \ldots
$$

can be used as a summary measure of inequality and moreover is a member of the "illfare-ranked single-series Ginis" class introduced by Donaldson and Weymark (1980). As noted by Aaberge (2000), $I_{1}$ is actually equivalent to a measure of inequality that was proposed by Bonferroni (1930), whilst $I_{2}$ is the Gini coefficient. ${ }^{11}$ In this paper we will measure individual welfare level with a common utility function (see Section 4).

To ease the interpretation of the inequality aversion profiles exhibited by $W_{1}, W_{2}, W_{3}$ and $W_{\infty}$ Table 4.2 provides ratios of the corresponding weights - as defined by (4.4) - of the median individual and the 1 per cent poorest, the 5 per cent poorest, the 30 per cent poorest and the 5 per cent richest individual for different social welfare criteria. As can be observed from the weight profiles provided by Table $4.2 W_{1}$ will be particular sensitive to changes in policies that affect the welfare of the poor.

\footnotetext{
${ }^{11}$ For further discussion of the family $\left\{I_{k}: k=1,2, \ldots\right\}$ of inequality measures we refer to Mehran (1976), Donaldson and Weymark (1980, 1983), Bossert (1990) and Aaberge (2000, 2001).
} 
Table 4.2. Distributional weight profiles of four different social welfare functions

\begin{tabular}{|lcccc|}
\hline & $\begin{array}{c}W_{1} \\
\text { (Bonferroni) }\end{array}$ & $\begin{array}{c}W_{2} \\
\text { (Gini) }\end{array}$ & $W_{3}$ & $\begin{array}{c}W_{\infty} \\
\text { (Utilitarian) }\end{array}$ \\
$\mathrm{p}(.01) / \mathrm{p}(.5)$ & 6.64 & 1.98 & 1,33 & 1 \\
$\mathrm{p}(.05) / \mathrm{p}(.5)$ & 4.32 & 1.90 & 1.33 & 1 \\
$\mathrm{p}(.30) / \mathrm{p}(.5)$ & 1.74 & 1.40 & 1.21 & 1 \\
$\mathrm{p}(.95) / \mathrm{p}(.5)$ & 0.07 & 0.10 & 0.13 & 1 \\
\hline
\end{tabular}

For a given total welfare (i.e. the sum of individual welfare levels) the welfare functions $W_{1}$, $W_{2}$, and $W_{3}$ take their maximum value when everyone get the same welfare level.

\section{Evaluation of the 2007-08 tax-credit reform}

\subsection{Income, welfare and working hours}

Table 5.1 summarizes the welfare effects of the tax reform based on three alternative common utility functions. One where the exogenous variables of the deterministic part of the utility function are replaced by the sample mean values, the second by the mean values of the poorest (in terms of income) 10 per cent and the third by the mean values of the richest 10 per cent. The results show that the overall mean welfare increases between 3.3 and 5.3 per cent; depending on whether one uses the common utility function based on the exogenous mean values of the poorest or the richest income decile. Moreover, the results for the winners are very similar, whereas there are larger variation in welfare means across deciles when using the poor related common utility function. Note that the identification of the proportions of winners and losers solely requires ordinal utility information. Thus, the estimates of the proportions of winners and losers are independent of the choice of common utility function. As demonstrated by Table 5.1 a majority of 63.3 per cent has gained from the in-work tax credit reform. However, there is also a large part with unchanged welfare (33.9 per cent) and hence less than 3 per cent who has lost. The proportions of gainers and losers vary across deciles of the pretax income distribution. For the 10 per cent poorest individuals there are equally many with unchanged utility as there are winners. The reason for unchanged welfare is that these individuals don't change their labor supply and that their incomes are below the norm for social assistance. Hence, as illustrated in Figure 2.2, the tax credit has no effect on disposable income and therefore income remains the same as before the reform. Who are the losers? For the low income households, the main explanation is that they get income from social assistance before but not after the reform. As indicated by Figure 2.2 an increase in working hours might not result in an increase in disposable income or only a small 
increase, as long as the income is below the norm. A small or zero increase in disposable income and sometimes large increase in working hours result in a decrease in utility.

As income increases the proportion of gainers also increase, although not monotonically. Note that also at higher income there are some individuals that are losers; the reason is again social assistance and as we have mentioned before social assistance is an in-work benefit and even at relatively high income an individual can be eligible.

(table 5.1 about here)

Table 5.2summarizes the results of the reform on household disposable income. The static evaluation, no change in working hours, shows that, on average for all individuals, disposable income increased by $4.7 \%$, the corresponding dynamic result is $5.7 \%$. Table 5.3 shows that this difference is explained by an average increase in working hours by $2.7 \%$. This might give the impression that allowing for changes in working hours does not have a major effect. However, across the income distribution the results are dramatically different between the static and dynamic evaluation. The average increase in disposable income for all individuals with a before reform net- income below the 10 'th percentile is almost $10 \%$ in the dynamic evaluation compared to only $2 \%$ in the static. This is in accordance with expectations, the work requirement makes work pay and this has an effect on the lower income where participation rates and hours are low.

(table 5.2 about here)

The overall participation rate is 0.83 compared to only 0.36 in the lowest income decile. For the low income households the reform results in an increase in participation more than $20 \%$, and an increase in hours of almost $40 \%$. There is a strong effect on the participation rate up to percentile 30 but a much smaller effect for higher income. The effect on hour's conditional on working, the intensive margin, is in general much smaller but still a sizable effect on those below the third decile, note that for higher income there is even a small decrease in hours. For higher income the income effect of the tax cut dominates whereas for lower income it is the substation effect. But again the most important effect is the increased participation rate.

(table 5.3 about here)

Of course the change in working hours also affects social assistance. Table 5.4 shows that welfare participation drops by almost $20 \%$ and the amount more than $17 \%$. Again, these effects are much stronger compared to a static evaluation and also the distributional impact is completely 
different. For household with a low income (below decile 4) there is a decrease in participation between $22-30 \%$. Note that even high income household has a decrease. This is partly due to the fact that social assistance reflects family size and if the mother has many children it is possible to get assistance even if earnings are relatively high, but it also reflects that income is high because social assistance is included in the income.

(table 5.4 about here)

\subsection{The cost of the tax and benefit reform}

In this section we focus on the effects on government tax revenues and expenditures. Total taxes and benefits were calculated for each household before and after the reform, and then the weighted population-sums were calculated. Revenues were calculated as the sum of income and payroll taxes, plus Value-Added Taxes (VAT) and also the childcare fees paid by household. The cost of the reform was calculated as the amount of housing allowances and social assistance received by the household. Table 5.5 summarizes the total effects of the reform with and without labor supply adjustments. Before the reform the net revenue is SEK 28,194 million (USD 3,065): The static evaluation shows that the net revenue drops $5 \%$. The major impact is the drop in income tax revenues, (16\%), payroll taxes and revenues from childcare fees does not change since earning are unchanged, however since disposable income increase VAT goes up (5\%). On the expenditure side social assistance is reduced slightly (-2\%).

(table 5.5 about here)

Allowing for labor supply adjustments, the drop in income taxes is smaller (-13\%) since earnings have increased due to an increase in working hours, payroll taxes, VAT and child care fees have increased as well. There is a strong reduction in both housing allowance $(-7 \%)$ and social assistance (-17\%).

To summarize, despite the large tax cuts the dynamic effects, shows that the reform was almost revenue-neutral, the decrease in $1 \%$ implies a deficit of less than 300 million SEK, which correspond to less than $0,03 \%$ of total tax revenues in 2004 . Government revenues from income taxes and childcare fees dropped but this was compensated for by increased revenues from payroll taxes and VAT, as well as reduced cost for housing allowance and social assistance. 


\section{Conclusions}

The results, accordingly to the estimated model, suggest that a 1 percent wage increase corresponded to an average increase in hours of work of 0.3 pecent, the main effect is on the extensive margin and the effects are much stronger on low income households than on wealthier households. The income effects are smaller.

The main results of the evaluation of the tax reform show that on average, disposable income ${ }^{12}$ increased by almost 6 percent, working hours by almost 3 percent, whereas social assistance participation decreased by almost 20 percent. We found welfare-gains for almost everyone single mother. On average, there was a 6 percent increase in welfare for the entire population of single mothers. The most important effect of our reform was the increase in working hours for low-income households. In the first income decile there was an average increase of almost 40 percent.

The proposed tax and benefit reform proved to be more or less self-financed, due to the significant reduction in cost of social assistance.

\footnotetext{
12 Disposable income is defined as total income including social assistance housing allowance but excluding taxes and cost of child care.
} 


\section{References}

Aaberge, R. (2000): Characterizations of Lorenz Curves and Income Distributions, Social Choice and Welfare, 17, 639-653.

Aaberge, R. (2001): Axiomatic Characterization of the Gini Coefficient and Lorenz Curve Orderings, Journal of Economic Theory, 101, 115-132.

Aaberge, R., J.K. Dagsvik and S. Strøm (1995): "Labor Supply Responses and Welfare Effects of Tax Reforms", Scandinavian Journal of Economics, 97, 4, 635-659.

Aaberge, R., U. Colombino and S. Strøm (1999): "Labor Supply in Italy: An Empirical Analysis of Joint Household Decisions, with Taxes and Quantity Constraints", Journal of Applied Econometrics, 14, 403-422.

Aaberge, R., U. Colombino and S. Strøm (2004): "Do More Equal Slices Shrink the Cake? An Empirical Investigation of Tax-Transfer Reform Proposals in Italy", Journal of Population Economics, 17, 4.

Aaberge, R., U. Colombino and T. Wennemo (2006): "Evaluating Alternative Representations of the Choice Sets in Models of Labour Supply", Discussion Paper No. 1985, IZA, Bonn, 2006.

Aaberge, R. and U. Colombino (2008): Designing Optimal Taxes with a Microeconometric Model of Household Labour Supply. CHILD Working Paper no. 06/08, CHILD - Centre for Household, Income, Labour and Demographic economics - Torino, Italy.

Beland, F, Birch, S, Stoddart, G. (2002): "Unemployment and health: contextual level influences on the production of health in populations", Social Science and Medicine,2033-52.

Ben Porath, E. and I. Gilboa (1994): "Linear Measures, the Gini Index, and the IncomeEquality Trade-off”, Journal of Economic Theory, 64, 443-467.

Boadway R., Marchand M., Pestieau P. and M. Racionero (2002): "Optimal Redistribution with Heterogeneous Preferences for Leisure”, Journal of Public Economic Theory, 4, 475 498.

Bossert, W. (1990): An Approximation of the Single-series Ginis, Journal of Economic Theory, 50,

$82-92$.

Blundell, R., J. Ham, and C. Meghir (1992):” Unemployment and Female Labour Supply”, Economic Journal, 97, 44-64.

Blundell, R., Hoynes, H. 2003. Has "in-work" benefit reform helped the labour market? In: Card, D., Blundell, R., Freeman, R.B. (Eds), Seeking a premiere economy: the economic effects of British economic reforms, 1980-2000. Forthcoming from The University of Chicago Press, 
http://www.nber.org/books/bcf/blundell-hoynes2-3-03.pdf

Bonferroni, C. (1930): Elementi di Statistica Generale. Seeber, Firenze.

Dagsvik, J.K. (1994): Discrete and Continuous Choice, Max-Stable Processes and Independence from Irrelevant Attributes, Econometrica, 62, 1179-1205.

Dickens, W. and S. Lundberg (1993): Hours Restrictions and Labour Supply, International Econonomic Review, 34, 169-191.

Donaldson, D. and J.A. Weymark (1980): A Single Parameter Generalization of the Gini Indices of Inequality, Journal of Economic Theory, 22, 67-86.

Donaldson, D. and J.A. Weymark (1983): Ethically flexible Indices for Income Distributions in the Continuum, Journal of Economic Theory, 29, 353-358.

Duncan, A., Giles, C. 1998. The labour market impact of the working families tax credit in the U.K.. Working paper, University of Nottingham:

http://www.nottingham.ac.uk/ lezad/work/.

Edin, P. A., and Fredriksson, A., "LINDA - Longitudinal INdividual DAta for Sweden" www.nek.uu.se/ (2000).

Euwals, R. and A. van Soest (1999), "Desired and actual labor supply of unmarried men and women in the Netherlands", Labor Economics, 6, 95-118.

Fang H. and Keane M. (2004) 'Assessing the Impact of Welfare Reform on Single Mothers', Brookings Papers on Economic Activity 1: 1-116.

Fleurbaey, M. and F. Maniquet (2006): Fair Income Tax, Review of Economic Studies, 73, 5584.

Flood, L., J. Hansen and R. Wahlberg (2004): "Household Labor Supply and Welfare Participation in Sweden”, Journal of Human Resources, 39, 1008 - 1032.

Flood, L.,R. Wahlberg and E. Pylkänen (2007), "From Welfare to Work: Evaluating a Proposed Tax and Benefit Reform Targeted at Single Mothers in Sweden”, LABOUR, 21, $443-471$

Governmental budget proposition 2008. 2007/08:1

Hammond, P.J. (1991): "Interpersonal Comparisons of Utility: Why and How They Are and Should Be Made?". In Elster, J. and J. E. Roemer (eds.): Interpersonal comparisons of wellbeing. Studies in Rationality and Social Change, Cambridge; New York and Melbourne: Cambridge University Press in collaboration with Maison des Sciences de l'Homme, 1991; 200-254.

Hey, J. D. and P. J. Lambert (1980): Relative Deprivation and the Gini Coefficient: Comment, Quarterly Journal of Economics, 94, 567-573. 
Johansson, P. and M. Palme (2002) "Assessing the effects of a compulsory sickness insurance on worker absenteeism", Journal of Human Resources, 37, 381-409.

Labeaga, J.M., X. Oliver and A. Spadaro (2007): "Discrete choice models of labour supply, behavioural microsimulation and the Spanish tax reforms", The Journal of Economic Inequality, DOI 10.1007/s10888-007-9057-9.

Lindbeck, A., Palme., M., Persson, M (2007): Social Interaction and Sickness Absence. IFN Working Paper No. 725

Mehran, F. (1976): “Linear Measures of Inequality”, Econometrica, 44, 805-809.

Meyer, B.D., D.T. Rosenbaum (2001): "Welfare, the earned income tax credit, and the labor supply of single mothers", Quarterly Journal of Economics, 116, 1063-1114.

Moffitt, R. (1983):" An economic model of welfare stigma", American Economic Review, 73, 1023-1035.

Sen, A. (1974): "Informational Bases of alternative Welfare Approaches", Journal of Public Economics, 3, 387-403.

Statistics Sweden (2004), Income Distribution Survey 2004. HE 21 SM 0601

Weymark, J. (1981): Generalised Gini Inequality Indices, Mathematical Social Sciences, 1, 409-430.

Yaari, M.E. (1988): A controversial Proposal Concerning Inequality Measurement, Journal of Economic Theory, 44, 381-397. 


\section{Appendix 1}

\section{Description of the data}

The data was taken from the Swedish register-based LINDA ${ }^{13}$. LINDA consists of a large panel of individuals and their household members; the sample used in this study comes from the 2004 wave of LINDA. We included single mothers older than 24 and younger than 56 with 1 to 5 children, the youngest being 17 year or younger. The lower age limit exclude the problem of modeling choice of education and the upper follows from the age limit of youngest children, only a few full time students older than 25 were excluded. Information on incomes, wages, transfers, taxes, educational attainments was obtained from various government registers.

The definition of a household is a problem in most administrative data, and LINDA is no exception. For economic analysis the most natural would be to define "household" as an economic unit, but since LINDA is based completely on register information it is not always possible to get correct information about the household composition. There is then a possibility that the number of single mothers may be overestimated if, for instance, she is living together with a man without being married and without having common children. We have not tried to adjust for this, but according to alternative data sources ${ }^{14}$, which are surveybased and therefore use an economic definition, the differences are quite small. About $5 \%$ of all households in Sweden 2004 can be classified as headed by single mothers.

Wage data was collected from the official statistics by Statistics Sweden, based on employers' reports. Employers report monthly earnings, expressed in full-time equivalents and giving the amount the individual would have earned if working full-time. To obtain hourly wage rates, the monthly earnings are divided by 165 . Yearly hours of work, $\mathrm{h}$, is then defined as total labor earnings divided by the hourly wage rate. The hourly wage rate used here is quite different from that obtained by dividing observed earnings by observed hours, which has a tendency to include measurement errors. The data used here is not subject to the same problem. However, there are missing values from the employers reported earnings and if there is a positive reported income from work but no monthly earnings reported from the employer, then we delete that individual. Thus, we are deleting some of the workers and to

\footnotetext{
${ }^{13}$ For a description of LINDA see Edin and Fredriksson (2000).

${ }^{14}$ Statistics Sweden (2004), Income distribution Survey 2004.
} 
compensate for this we have also deleted some non-workers randomly in order to keep the participation rate intact. We ended up with a sample of 3,600 single mothers.

As usual, a remaining problem is that wage rates are missing for non-working individuals. Note that the labor supply model also includes estimation of a wage equation. Still a wage equation is estimated and based on the estimates predicted mean values and variances are used for data generation.

The total income of a household consists of both earned and unearned income. Unearned incomes include any capital gains, the national child allowance, and any childsupport payments. Unemployment benefits and other transfers that depend on labor supply were excluded from our measure of unearned income.

Unfortunately, there is no information in LINDA about housing rent or about how many households use municipal childcare. Therefore, the rent of housing was imputed using information from an alternative data source, the Swedish Household Income Survey 2004, also supplied by Statistics Sweden. In the imputation we used the method of minimumdistance, using age, number of children, earnings, place of residence, and citizenship as classification variables. The childcare fees could still be calculated since the rules are known and since the take-up ratio is high we assume that everyone utilize municipal child-care.

In LINDA there is register-information on the number of months each household received social assistance (as well as the amount received), but not which months. ${ }^{15}$ Thus we were not able use monthly data in the analysis, but instead aggregated all information to an annual basis. A household is then defined as a recipient if it received more than SEK 12,000 during the year. Most of the SA-households received benefits for a short period. Of all the SA-recipients, about $60 \%$ received it for six months or less.

To generate disposable income for various combinations of hours of work and welfare, we use a modified version of the micro-simulation model (FASIT). ${ }^{16}$ FASIT contains very precise information on income tax rules, as well as eligibility-rules for a number of welfare programs, such as social assistance and housing allowance. It also enabled us to calculate cost of childcare. Access to a simulation-model such as FASIT was essential for calculating accurate (net) household incomes, conditional on labor supply, because income tax rules and the various welfare benefit-levels are complicated functions of earned and unearned income.

The variables included in the utility function were: age, education, dummy variables

\footnotetext{
${ }^{15}$ Having access to register-data on welfare participation is a great advantage compared to interview-data, as there is no under-reporting of welfare participation in register-data.
} 
for the age of the children; a dummy variable indicating if the single mother was born in Sweden; and finally, years of experience.

In this study the sample has been divided into employed, unemployed, long-term sickness, disability pension and also voluntary non-workers (individuals not supported on unemployment or sick/disability benefit). The classification into these groups is done according to the income source. An individual with the bulk part of her income from work is classified as employed, if most of the income comes from unemployment benefit the individual is classified as unemployed and so on. The income limits has been selected in such way that the results is comparable to information from Statistical Sweden, based on the labor force study.

Table A.1 presents descriptive statistics for the sample used for the empirical analysis. The information is given for the total as well as for each sub-group. The bottom line shows that out of the total 3,600 households, $73 \%$ are employed and $6 \%$ classified as other that is individuals without support from disability/sickness/unemployment-benefit. The "outsiders" are of equal size, unemployed $7 \%$, disability and sickness $6 \%$. In general, the characteristics of the non-employed individuals differ from the employed. For instance, only $2 \%$ of individuals classified as disabled have the highest education compared to $18 \%$ for the employed. Age and years of experience indicate that unemployed are younger and disabled are older. The distribution of children is similar with the exception that the younger children are more frequent amongst unemployed and other. Among those employed almost $70 \%$ are in the public sector.

(table A.1 about here)

For the distribution of income and working hours across the different groups, it is important to remember that the outsiders can work part of the year. It follows from the statistics that the overall participation rate is about $80 \%$ and that a large share of unemployed and long-term sick have had some working spell during the year but much less so for disabled. However, information on working hours shows that they had worked few hours. Since working hours and distribution of hours is of a major interest in this study Figure 5.1 gives the frequencies for working hours for the full sample and Figure 5,2 for the "outsiders". The high ratio of non-participation and the presence of short working hours is a result of

\footnotetext{
${ }^{16}$ FASIT was developed and is used by Statistics Sweden and the Swedish Ministry of Finance.
} 
including the "outsiders".

Income from work of course reflects working hours and to some degree differences in wage rates. Non-labor income includes income of capital and some non-means tested transfers. Note that the mean of non-taxable non-labor income is negative, thus loans are frequent especially for those with a labor income. Even if there are large differences in labor income as expected the differences in disposable income is much smaller.

Disability/sickness/unemployment-benefit as well as social assistance is the main explanation. On average $6 \%$ of the sample has received more than SEK 12,000 during the year. It follows that there is a large across-group variation; from $66 \%$ for "other" to $1 \%$ for employed. 


\section{Tables}

Table A.1. Descriptive statistics a 2004 Linda sample of single mothers

\begin{tabular}{|c|c|c|c|c|c|c|}
\hline Variable & Total & Disability & Unemployed & Other & Sickness & Working \\
\hline Age & 40.72 & 43.39 & 37.67 & 39.14 & 39.69 & 41.01 \\
\hline Highest education first level & 0.16 & 0.37 & 0.20 & 0.50 & 0.24 & 0.11 \\
\hline Highest education secondary level & 0.69 & 0.61 & 0.74 & 0.46 & 0.68 & 0.71 \\
\hline Highest education tertiary level & 0.15 & 0.02 & 0.06 & 0.04 & 0.07 & 0.18 \\
\hline Years of working experience & 19.84 & 23.87 & 17.47 & 20.75 & 19.83 & 19.65 \\
\hline Born in Sweden yes $=1$ & 0.83 & 0.75 & 0.72 & 0.54 & 0.81 & 0.87 \\
\hline Number of children age $0-5$ & 0.13 & 0.09 & 0.27 & 0.30 & 0.15 & 0.10 \\
\hline Number of children age 6-12 & 0.60 & 0.43 & 0.78 & 0.83 & 0.69 & 0.57 \\
\hline Number of children age 13-17 & 0.70 & 0.87 & 0.51 & 0.61 & 0.71 & 0.70 \\
\hline Employed in public sector, yes $=1^{*}$ & 0.69 & 0.00 & 0.86 & 0.00 & 0.51 & 0.69 \\
\hline Working, yes $=1$ & 0.81 & 0.04 & 0.58 & 0.00 & 0.46 & 1.00 \\
\hline Yearly working hours & 1398 & 7 & 297 & 0 & 231 & 1849 \\
\hline Hourly wage rate & 128 & 120 & 119 & 120 & 122 & 130 \\
\hline Yearly earnings (WH) & 194842 & 2059 & 46078 & 3364 & 159460 & 243424 \\
\hline Yearly Taxable non-labor income & 11416 & 19449 & 18497 & 31 & 10514 & 8661 \\
\hline Yearly non-taxable non-labor income ${ }^{* *}$ & -2072 & 110 & 1094 & 1901 & -1427 & -2924 \\
\hline Deductions $^{* * *}$ & 3800 & 568 & 1152 & 293 & 1488 & 4835 \\
\hline Yearly Net income & 197471 & 173638 & 170291 & 146 & 179862 & 207772 \\
\hline Social assistance, yes $=1$ & 0.06 & 0.12 & 0.08 & 0.66 & 0.10 & 0.01 \\
\hline Outsider, yes $=1^{* * * * *}$ & 0.21 & 1.00 & 1.00 & 0.00 & 1.00 & 0.00 \\
\hline Share & 1.00 & 0.06 & 0.07 & 0.06 & 0.08 & 0.73 \\
\hline
\end{tabular}

Source: LINDA 2004

Note, Total sample size 3600

*) Calculations based on 2703 individuals, who are $1=$ public and $0=$ privately employed and 297 individuals are not employed.

**) The negative mean value is explained by negative capital.

***) Deductions are mainly cost of commuting to work and part of premium for private pension savings.

$* * * *$ ) Unemployed, disability pension and long term sick, yes $=1$ 
Table 3.1. Estimates of the parameters of the utility function

\begin{tabular}{|c|c|c|c|}
\hline Variable & Parameter & Estimate & Std. Dev. \\
\hline \multicolumn{4}{|l|}{ Consumption } \\
\hline & $\alpha_{1}$ & 0.63488 & 0.04636 \\
\hline & $\alpha_{2}$ & 5.74491 & 0.14556 \\
\hline \multicolumn{4}{|l|}{ Leisure } \\
\hline & $\alpha_{3}$ & -20.72082 & 1.40525 \\
\hline Constant & $\alpha_{4}$ & 6.64993 & 2.72286 \\
\hline Log age & $\alpha_{5}$ & -3.51460 & 1.44434 \\
\hline Log age squared & $\alpha_{6}$ & 0.47278 & 0.19464 \\
\hline \# children, 0 - 5 years old & $\alpha_{7}$ & 0.01753 & 0.01280 \\
\hline \# children, 6 - 12 years old & $\alpha_{8}$ & 0.00879 & 0.00544 \\
\hline \# children, 13 - 17 years old & $\alpha_{9}$ & -0.00379 & 0.00476 \\
\hline Employed in public sector & $\alpha_{10}$ & -0.01846 & 0.01479 \\
\hline Disabled, unemployed or long-term sick & $\alpha_{11}$ & 2.30343 & 0.55256 \\
\hline Consumption * Leisure & $\alpha_{12}$ & -0.16244 & 0.06622 \\
\hline \multicolumn{4}{|l|}{ Disutility } \\
\hline$z \times Q_{2}=1$ if children, $1-2$ years old & $\tau_{1}$ & 2.19878 & 0.52755 \\
\hline$z \times Q_{3}=1$ if children, 3 years old & $\tau_{2}$ & 2.05128 & 0.37065 \\
\hline $\mathrm{z} \times \mathrm{Q}_{4}=1$ if children, $4-6$ years old & $\tau_{3}$ & 0.75062 & 0.22771 \\
\hline$z \times Q_{5}=1$ if children, 7 - 10 years old & $\tau_{4}$ & 0.72422 & 0.18283 \\
\hline $\mathrm{z} \times \mathrm{Q}_{6}=1$ if children, $11-14$ years old & $\tau_{5}$ & -0.41188 & 0.18015 \\
\hline $\mathbf{z} \times \mathbf{Q}_{7}=1$ if Nationality=Swedish $(=1)$ & $\tau_{6}$ & -1.37997 & 0.18644 \\
\hline$z \times Q_{8}=1$ if lowest education $(\mathrm{de}=1)$ & $\tau_{7}$ & 1.56291 & 0.19105 \\
\hline
\end{tabular}


Table 3.2. Estimates of the choice set parameters.

\begin{tabular}{|c|c|c|c|}
\hline & Parameter & Estimate & Std. Dev. \\
\hline Market relative to non-market social assistance opportunities & $\boldsymbol{\theta}$ & -5.53127 & 0.24647 \\
\hline \multicolumn{4}{|l|}{ Job/social assistance opportunity } \\
\hline public*social assistance & $\mu_{11}$ & -7.45103 & 0.33621 \\
\hline public*not social assistance & $\mu_{12}$ & -5.16508 & 0.23798 \\
\hline private $^{*}$ social assistance & $\mu_{21}$ & -7.20378 & 0.44203 \\
\hline private* not social assistance & $\mu_{22}$ & -4.14759 & 0.28740 \\
\hline public* social assistance *outsider & $\mu_{31}$ & -1.79508 & 0.83901 \\
\hline public* not social assistance *outsider & $\mu_{32}$ & -3.08028 & 0.25691 \\
\hline private* social assistance *outsider & $\mu_{41}$ & 0.63595 & 0.70360 \\
\hline private* not social assistance *outside & $\mu_{42}$ & -1.51998 & 0.24582 \\
\hline \multicolumn{4}{|l|}{ Hours - Public sector } \\
\hline Part time & $\gamma_{11}$ & 0.48357 & 0.16771 \\
\hline Full time & $\gamma_{12}$ & 1.18056 & 0.12608 \\
\hline \multicolumn{4}{|l|}{ Hours - Private sector } \\
\hline Part time & $\gamma_{21}$ & -0.76408 & 0.20988 \\
\hline Full time & $\gamma_{22}$ & 0.12767 & 0.14307 \\
\hline \multicolumn{4}{|l|}{ Wage - Public sector } \\
\hline Constant & $\beta_{10}$ & 4.40299 & 0.01989 \\
\hline Experience/100 & $\beta_{11}$ & 0.88989 & 0.17190 \\
\hline Experience squared & $\beta_{12}$ & -1.59782 & 0.44083 \\
\hline High school & $\beta_{13}$ & 0.11401 & 0.01193 \\
\hline University & $\beta_{14}$ & 0.34577 & 0.01361 \\
\hline Standard deviation & $\sigma_{1}$ & 0.15377 & 0.00200 \\
\hline \multicolumn{4}{|l|}{ Wage - Private sector } \\
\hline Constant & $\beta_{20}$ & 4.40637 & 0.03188 \\
\hline Experience/100 & $\beta_{21}$ & 1.32833 & 0.28458 \\
\hline Experience squared & $\beta_{22}$ & -3.21117 & 0.70755 \\
\hline High school & $\beta_{23}$ & 0.02743 & 0.01461 \\
\hline University & $\beta_{24}$ & 0.20837 & 0.01955 \\
\hline Standard deviation & $\sigma_{2}$ & 0.21423 & 0.00444 \\
\hline
\end{tabular}


Table 3.3. Labor supply elasticities with respect to wage for single mothers by deciles of disposable income*.

\begin{tabular}{|c|c|c|c|}
\hline $\begin{array}{c}\text { Income decile } \\
\text { under the pre- } \\
\text { reform system }\end{array}$ & $\begin{array}{c}\text { Elasticity of unconditional } \\
\text { expectation of hours ofwork }\end{array}$ & $\begin{array}{c}\text { Elasticity of the } \\
\text { probability of } \\
\text { participation }\end{array}$ & $\begin{array}{c}\text { Elasticity of conditional } \\
\text { expectation of hours of } \\
\text { work }\end{array}$ \\
\hline 1 & 4.69 & 2.73 & 0.64 \\
\hline 2 & 0.91 & 0.67 & 0.30 \\
\hline $3-8$ & 0.22 & 0.16 & 0.06 \\
\hline 9 & 0.02 & 0.06 & -0.04 \\
\hline 10 & 0.08 & 0.12 & -0.04 \\
\hline All & 0.34 & 0.30 & 0.10 \\
\hline
\end{tabular}

Table. 3.4. Labor supply elasticities with respect to non-labor income for single mothers by deciles of disposable income.

\begin{tabular}{|c|c|c|c|}
\hline $\begin{array}{c}\text { Income decile } \\
\text { under the pre- } \\
\text { reform system }\end{array}$ & $\begin{array}{c}\text { Elasticity of } \\
\text { unconditional } \\
\text { expectation of } \\
\text { hours of work }\end{array}$ & $\begin{array}{c}\text { Elasticity of the } \\
\text { probability of } \\
\text { participation }\end{array}$ & $\begin{array}{c}\text { Elasticity of } \\
\text { conditional } \\
\text { expectation of } \\
\text { hours of work }\end{array}$ \\
\hline 1 & 0.00 & 0.00 & 0.00 \\
\hline 2 & -0.01 & -0.04 & -0.04 \\
\hline $3-8$ & -0.02 & -0.03 & -0.03 \\
\hline 9 & 0.01 & 0.00 & 0.00 \\
\hline 10 & -0.08 & -0.09 & -0.09 \\
\hline All & -0.02 & -0.03 & -0.03 \\
\hline
\end{tabular}

1) the elasticities in Table 3.3 and 3.4 has been computed as an average of the percentage changes in labor supply from a 10 percent increase in the wage rates or non-labor income. 
Table 5.1. Change in welfare by losers and winners, and by income deciles under the pre-reform tax system ${ }^{1)}$

\begin{tabular}{|c|c|c|c|c|c|c|c|c|c|c|c|}
\hline \multirow{3}{*}{$\begin{array}{l}\text { Income } \\
\text { decile } \\
\text { under } \\
\text { the } \\
\text { pre- } \\
\text { reform } \\
\text { system }\end{array}$} & \multicolumn{3}{|c|}{ All } & \multicolumn{4}{|c|}{ Losers } & \multicolumn{4}{|c|}{ Winners } \\
\hline & \multicolumn{3}{|c|}{$\begin{array}{c}\text { Change in welfare } \\
\text { Per cent }\end{array}$} & \multirow[t]{2}{*}{$\begin{array}{l}\text { Per cent } \\
\text { of pop. }\end{array}$} & \multicolumn{3}{|c|}{$\begin{array}{c}\text { Change in welfare } \\
\text { Per cent }\end{array}$} & \multirow[t]{2}{*}{$\begin{array}{l}\text { Per cent } \\
\text { of pop. }\end{array}$} & \multicolumn{3}{|c|}{$\begin{array}{c}\text { Change in welfare } \\
\text { Per cent }\end{array}$} \\
\hline & I & II & III & & I & II & III & & I & II & III \\
\hline 1 & 4,0 & 3,7 & 4,5 & 2,8 & $-12,5$ & $-18,8$ & $-5,3$ & 46,9 & 9,7 & 11,8 & 7,8 \\
\hline 2 & 4,7 & 4,2 & 4,2 & 1,4 & $-6,2$ & $-8,9$ & $-8,0$ & 58,9 & 8,7 & 9,6 & 7,6 \\
\hline 3 & 3,9 & 3,6 & 4,2 & 1,6 & $-7,8$ & $-8,0$ & $-6,4$ & 54,9 & 8,1 & 8,7 & 7,4 \\
\hline 4 & 4,2 & 3,1 & 5,5 & 3,1 & $-5,5$ & $-6,8$ & $-4,8$ & 57,4 & 7,9 & 7,9 & 7,7 \\
\hline 5 & 3,6 & 2,8 & 5,2 & 3,1 & $-5,0$ & $-7,4$ & $-4,5$ & 52,6 & 8,0 & 7,2 & 7,9 \\
\hline 6 & 4,5 & 2,4 & 6,4 & 3,1 & $-3,5$ & $-7,5$ & $-4,8$ & 63,9 & 7,5 & 7,8 & 7,6 \\
\hline 7 & 4,6 & 3,3 & 6,1 & 1,1 & $-4,0$ & $-5,4$ & $-3,3$ & 68,1 & 7,3 & 7,0 & 7,6 \\
\hline 8 & 5,4 & 3,5 & 6,3 & 1,1 & $-5,0$ & $-4,2$ & $-4,0$ & 78,9 & 7,0 & 6,4 & 7,4 \\
\hline 9 & 4,6 & 3,6 & 6,0 & 0,8 & $-4,7$ & $-4,8$ & $-3,4$ & 74,2 & 7,0 & 5,9 & 7,0 \\
\hline 10 & 3,9 & 3,0 & 4,7 & 0,3 & $-3,0$ & $-3,8$ & $-1,5$ & 76,9 & 5,1 & 4,7 & 5,3 \\
\hline All & 4,4 & 3.3 & 5,3 & 2,8 & $-5,3$ & $-6,8$ & $-4,3$ & 63,3 & 7,4 & 7,1 & 7,2 \\
\hline
\end{tabular}

${ }^{1)} \mathrm{I}=$ common utility function defined in terms of the mean values of the single mothers $\mathrm{II}=$ common utility function defined in terms of the mean values of the 10 per cent poorest single mothers

$\mathrm{III}=$ common utility function defined in terms of the mean values of the 10 per cent richest single mothers 
Table 5.2. Direct and total effects on disposable income from the tax reform

\begin{tabular}{|c|c|c|c|}
\hline $\begin{array}{l}\text { Income decile under } \\
\text { the pre-reform system }\end{array}$ & $\begin{array}{c}\text { Disposable } \\
\text { income } \\
\text { SEK }\end{array}$ & $\begin{array}{c}\text { Direct effect } \\
\text { (static) } \\
\text { Per cent }\end{array}$ & $\begin{array}{l}\text { Total effect } \\
\text { (dynamic) } \\
\text { Per cent }\end{array}$ \\
\hline 1 & 115809 & 1.96 & 9.58 \\
\hline 2 & 144575 & 4.27 & 7.48 \\
\hline 3 & 158883 & 4.44 & 6.70 \\
\hline 4 & 171198 & 4.97 & 5.81 \\
\hline 5 & 182753 & 5.44 & 5.89 \\
\hline 6 & 194910 & 5.42 & 5.67 \\
\hline 7 & 207730 & 5.27 & 5.51 \\
\hline 8 & 222964 & 5.29 & 5.19 \\
\hline 9 & 241172 & 5.11 & 5.02 \\
\hline 10 & 286773 & 4.07 & 3.84 \\
\hline All & 192677 & 4.74 & 5.73 \\
\hline
\end{tabular}


Table 5.3 Effects on labour supply from the tax reform

\begin{tabular}{|c|c|c|c|c|c|c|}
\hline \multirow{2}{*}{ Income decile under } & \multicolumn{2}{|c|}{ Job participation } & \multicolumn{2}{c|}{ Hours of work conditional on working } & \multicolumn{2}{c|}{ Total hours of work } \\
\cline { 2 - 7 } the pre-reform system & Rate before & Change & Level before & Change & Level before & Change \\
& the reform & Per cent & the reform & Per cent & the reform & Per cent \\
\hline 1 & 0.36 & 21.09 & 1203 & 4.25 & 353 & 38.94 \\
\hline 2 & 0.75 & 5.56 & 1460 & 2.61 & 1033 & 7.92 \\
\hline 3 & 0.79 & 5.61 & 1528 & 0.49 & 1174 & 7.23 \\
\hline 4 & 0.86 & 0.65 & 1701 & 0.05 & 1381 & 1.35 \\
\hline 5 & 0.94 & 1.78 & 1644 & 0.17 & 1518 & 1.24 \\
\hline 6 & 0.93 & 0.90 & 1797 & -0.19 & 1636 & 1.09 \\
\hline 7 & 0.91 & 0.61 & 1868 & 0.17 & 1665 & 0.50 \\
\hline 8 & 0.91 & 0.30 & 1865 & -0.21 & 1705 & 0.19 \\
\hline 9 & 0.94 & 0.59 & 1948 & -0.36 & 1816 & -0.03 \\
\hline 10 & 0.93 & 1.20 & 1974 & -0.49 & 1831 & 0.67 \\
\hline 1 & 0.36 & 21.09 & 1203 & 4.25 & 353 & 38.94 \\
\hline & 2.61 & 1699 & 0.47 & 1411 & 2.71 \\
\hline
\end{tabular}


Table 5.4 Effect on social assistance

\begin{tabular}{|c|c|c|c|c|c|c|}
\hline Income decile & Average social & Direct effect & Total effect on & Pronortion & Direct effect & Chanoe \\
\hline under the & assistance & on received & received amounts & receiving & on number & dynamic \\
\hline pre-reform & before the & amounts & Per cent & social & of receivers & $\%$ \\
\hline system & reform & Per cent & & assistance & Per cent & \\
\hline & SEK & & & & & \\
\hline 1 & 19583 & -0.35 & -23.91 & 0.32 & 0.00 & -21.74 \\
\hline 2 & 11861 & -0.84 & -25.55 & 0.17 & -1.67 & -30.00 \\
\hline 3 & 17613 & -1.54 & -28.66 & 0.23 & -3.66 & -28.05 \\
\hline 4 & 8045 & -2.28 & -9.94 & 0.11 & -7.32 & -12.20 \\
\hline 5 & 6807 & -1.61 & -24.16 & 0.08 & 0.00 & -18.52 \\
\hline 6 & 7271 & -3.13 & -17.21 & 0.08 & -6.67 & -16.67 \\
\hline 7 & 9316 & -3.04 & -8.81 & 0.11 & -7.32 & -14.63 \\
\hline 8 & 7484 & -1.83 & -8.99 & 0.08 & 0.00 & -6.90 \\
\hline 9 & 7647 & -2.87 & -0.54 & 0.07 & -4.17 & -8.33 \\
\hline 10 & 16621 & -3.46 & -7.93 & 0.11 & -5.26 & -10.53 \\
\hline All & 11225 & -1.94 & -17.20 & 0.14 & -3.08 & -19.51 \\
\hline
\end{tabular}


Table 5.5 Governmental revenues before and after the reform, by direct and total effect

\begin{tabular}{|c|c|c|c|}
\hline & \multirow{2}{*}{$\begin{array}{c}\text { Before } \\
\text { the reform }\end{array}$} & \multicolumn{2}{|c|}{ Change due to the reform } \\
\hline & & $\begin{array}{c}\text { Direct effect } \\
\text { Per cent }\end{array}$ & $\begin{array}{c}\text { Total effect } \\
\text { Per cent }\end{array}$ \\
\hline Revenues & & & \\
\hline Income Taxes & 11929 & -16 & -13 \\
\hline Payroll Taxes & 11693 & 0 & 3 \\
\hline VAT & 7938 & 5 & 6 \\
\hline Child care fees & 613 & 0 & 4 \\
\hline Expenditures & & & \\
\hline Housing allowance & 1735 & 0 & -7 \\
\hline Social assistance & 2244 & -2 & -17 \\
\hline Revenues-Expenditures & 28194 & -5 & -1 \\
\hline
\end{tabular}

Notes: The payroll tax is $32,28 \%$ measured as a percentage of the wage rate net of payroll taxes. The VAT has been calculated as $20,6 \%$ on $100 \%$ of net-income. 


\section{Figures.}

Figure 1.1. Number of "whole-year-equivalent" in different benefit system 1970-2006. In thousand.

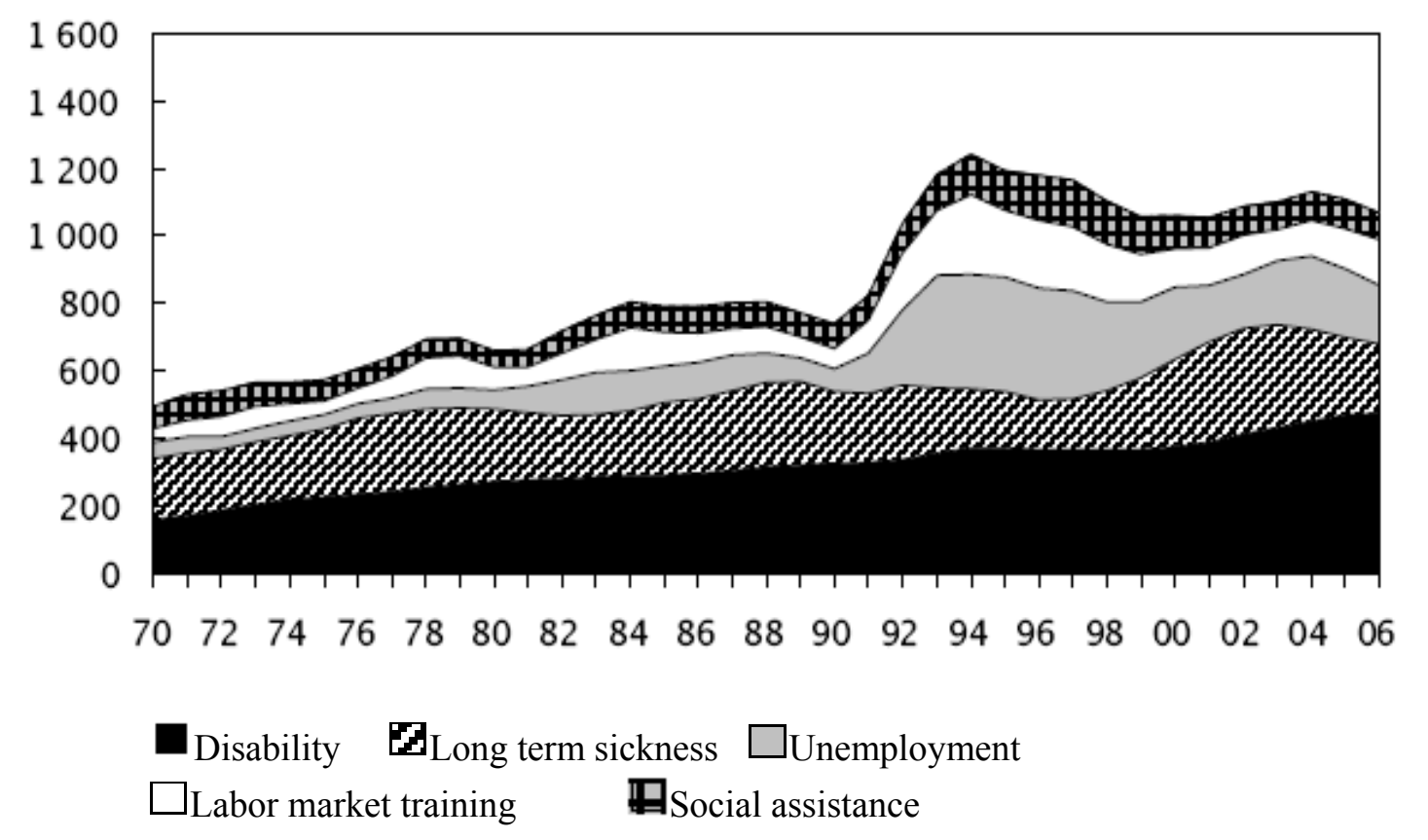

Source: Governmental budget proposition (2008). 
Figure 2.1. Marginal and average taxes before and after the reform

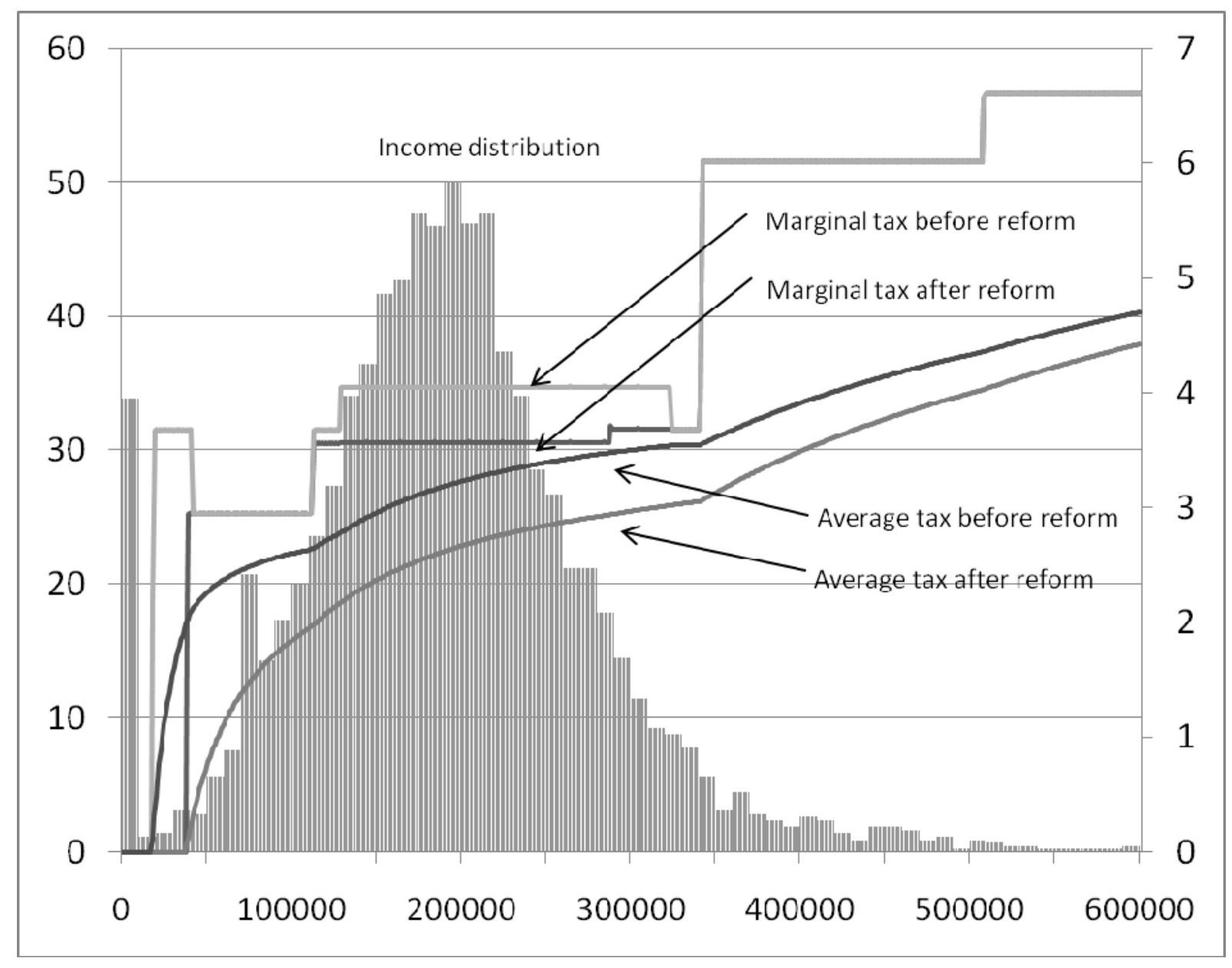

Note. For the income distribution use the scale on the right hand side. 
Figure 2.2. Disposable income for a low wage household

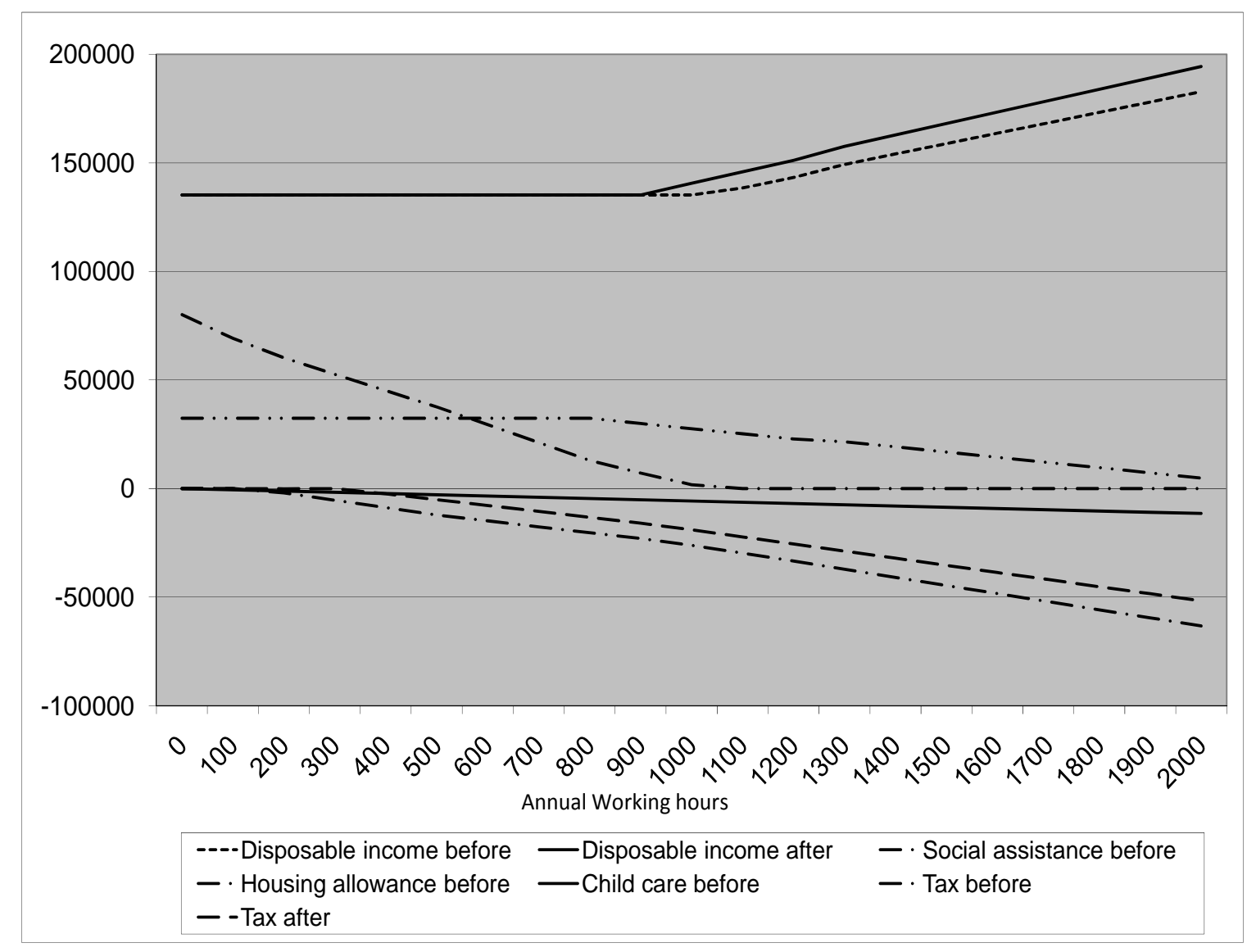


Figure 2.3 The basic tax deduction and in-work tax credit 2008

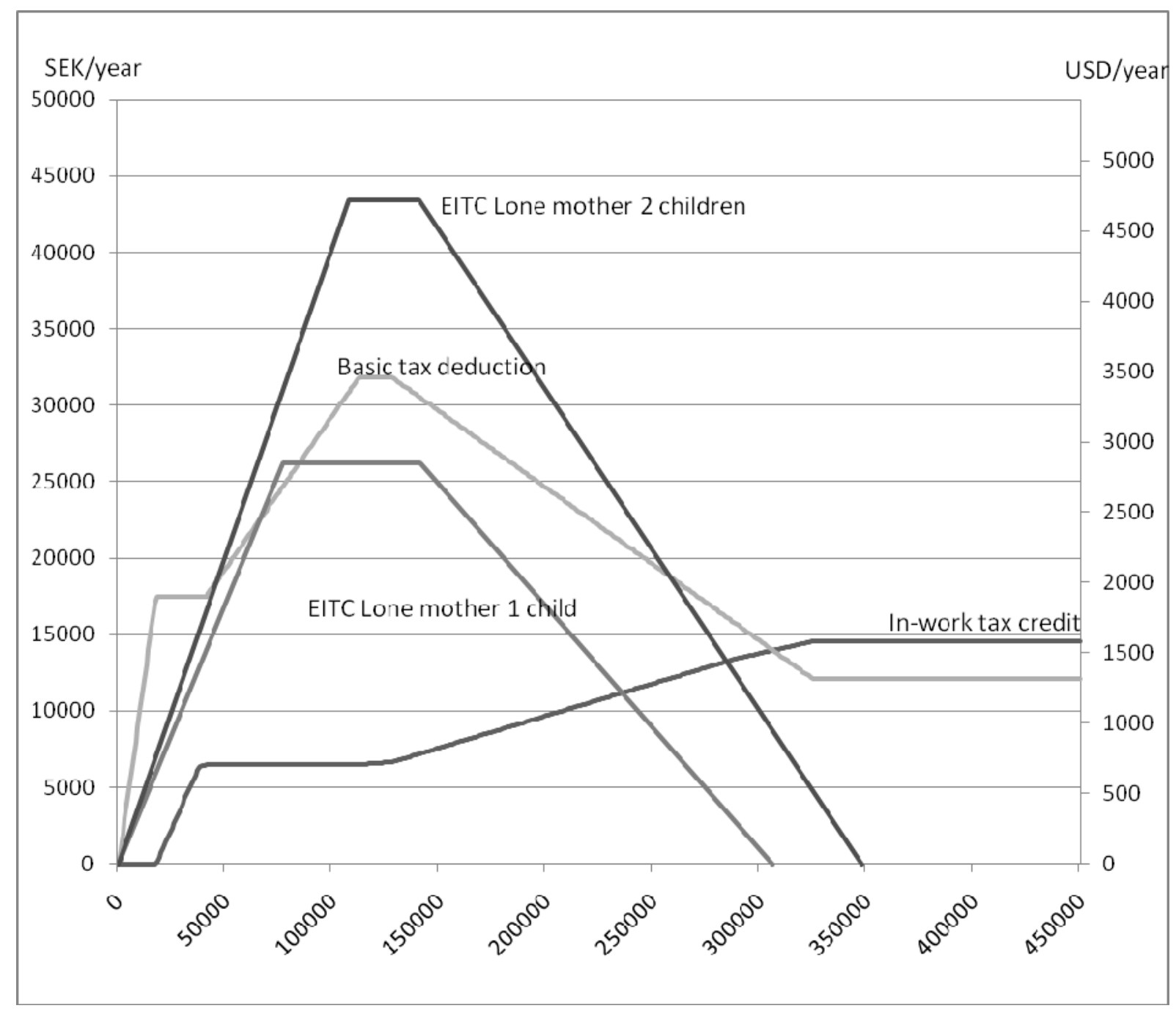


Figure 3.1. Distribution of observed and predicted hours, all individuals

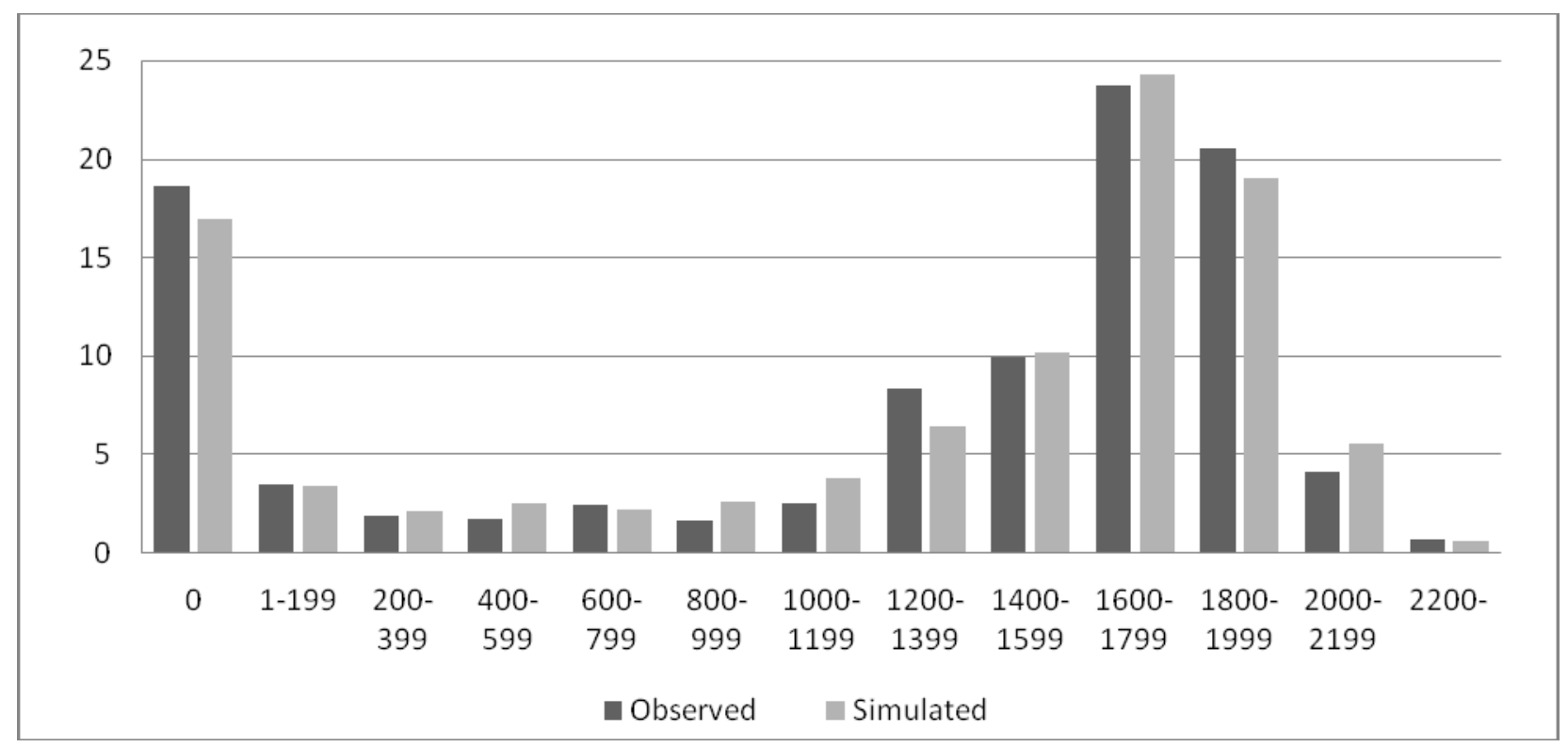

Figure 3.2. Distribution of observed and predicted hours, outsiders

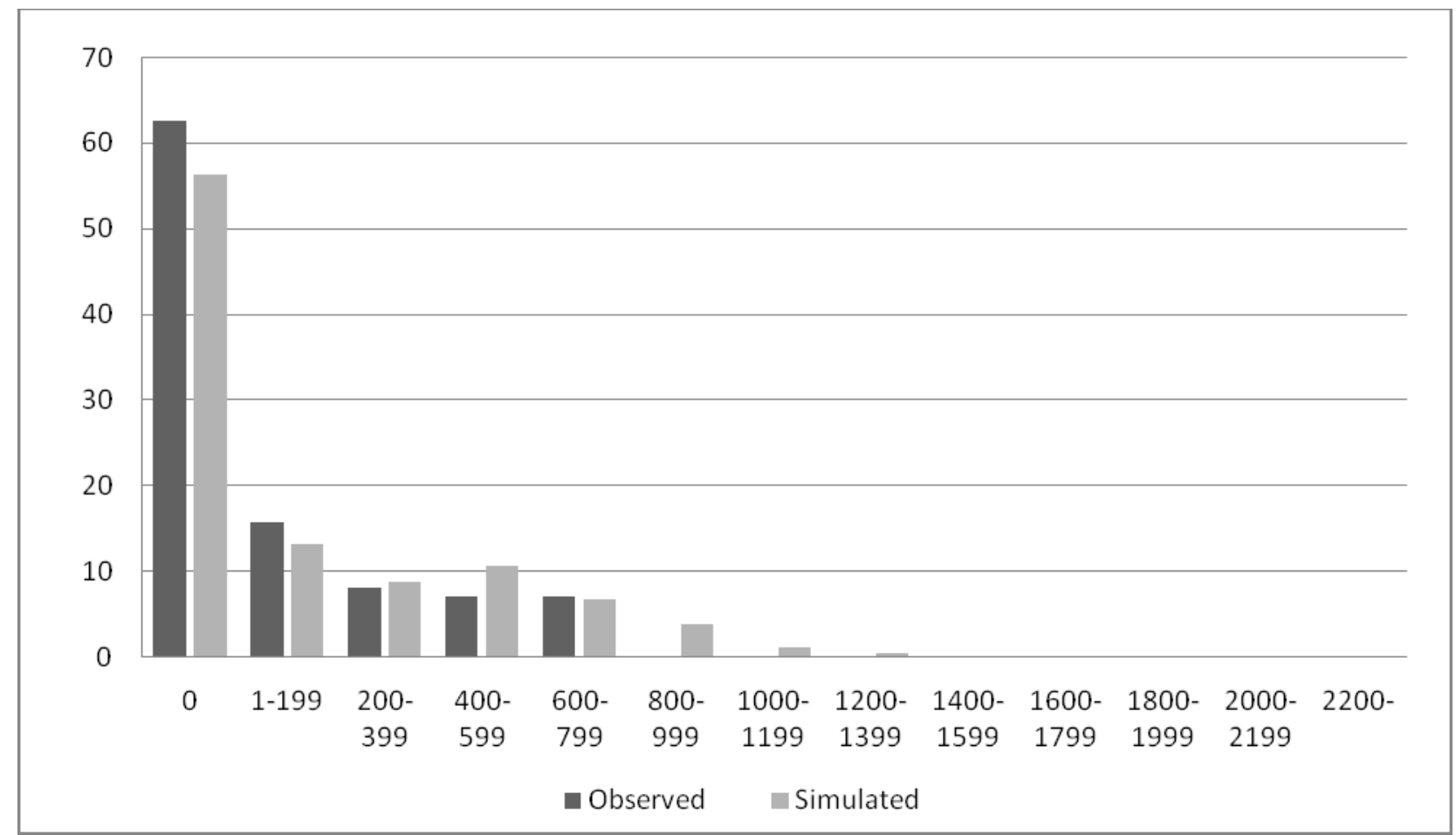

